( 2022 , The Authors. Published by Elsevier Inc. and Fass Inc. on behalf of the American Dairy Science Association ${ }^{\circledR}$. This is an open access article under the CC BY license (http://creativecommons.org/licenses/by/4.0/).

\title{
Early step-down weaning of dairy calves from a high milk volume with glutamine supplementation
}

\author{
H. K. J. P. Wickramasinghe, ${ }^{1} \odot$ C. A. Kaya, ${ }^{2} \odot$ L. H. Baumgard, ${ }^{1} \odot$ and J. A. D. R. N. Appuhamy ${ }^{1 *} \odot$ \\ ${ }^{1}$ Department of Animal Science, lowa State University, Ames 50011 \\ ${ }^{2}$ Department of Livestock and Crop Production, Dicle University, Diyarbakir 21280, Turkey
}

\section{ABSTRACT}

Weaning dairy calves from a high milk volume $(\geq 8.0$ $\mathrm{kg} / \mathrm{d}$ ) can negatively affect the growth and welfare even if it is performed in a step-down manner. Supplementation of Gln improved gut development of preweaning calves and mitigated weaning stresses of piglets to extents achieved with antibiotics. The study objective was to examine the effect of initiating a step-down weaning scheme with a Gln supplement at an early age on calf starter intake (CSI), average daily gain (ADG), and paracellular permeability of the intestinal epithelium of calves fed a high volume of milk $(9.0 \mathrm{~kg} / \mathrm{d})$. Thirty-six Holstein heifer calves were assigned to 3 treatments (n $=12$ ) as follows: (1) initiating weaning at $49 \mathrm{~d}$ of age (LW), (2) initiating weaning at $35 \mathrm{~d}$ of age (EW), and (3) initiating weaning at $35 \mathrm{~d}$ with a Gln supplement $(2.0 \%$ of dry matter intake) from 28 to $42 \mathrm{~d}$ of age (EWG). Calves were fed $9.0 \mathrm{~kg} / \mathrm{d}$ of whole milk until weaning was initiated by abruptly decreasing the milk volume to $3.0 \mathrm{~kg} / \mathrm{d}$. Weaning was completed once calves achieved $\geq 1.0 \mathrm{~kg} / \mathrm{d}$ of CSI. The paracellular permeability of the intestinal epithelium was assessed with lactulose-tomannitol ratio (LMR) in the blood on $1 \mathrm{~d}$ before, and 3 and $7 \mathrm{~d}$ after the initiation of weaning. The blood was analyzed for haptoglobin, lipopolysaccharide-binding protein (LBP), and metabolites including AA. The CSI increased once milk volume was restricted in all treatments. The CSI of LW was greater than that of EW and EWG during the first week of weaning. The LW, EW, and EWG took 11, 19, and $16 \mathrm{~d}$ to achieve $\geq 1.0$ $\mathrm{kg} / \mathrm{d}$ of CSI and were weaned at 60,54 , and $51 \mathrm{~d}$ of age, respectively. The body weight (BW) of LW, EW, and EWG at the initiation of weaning were 68.2, 58.7, and $59.5 \mathrm{~kg}$, respectively. Both LW and EWG achieved similar ADG, but ADG of EW was lower than LW during the first week of weaning. All calves had similar

Received July 14, 2021.

Accepted October 15, 2021.

*Corresponding author: appuhamy@iastate.edu
ADG during the second week of weaning. The BW of LW, EW, and EWG at weaning were 74.8, 66.5, and $66.4 \mathrm{~kg}$, representing a 2.0,1.8, and 1.8-fold increase in birth weight, respectively. All calves had similar BW of 88.6 and $164.3 \mathrm{~kg}$ at 10 and $20 \mathrm{wk}$ of age, respectively. Regardless of the age, serum haptoglobin and plasma LBP concentrations increased on $\mathrm{d} 3$ and returned to baseline concentrations on $\mathrm{d} 7$ during weaning. The EW had a lower plasma LBP concentration than LW and EWG on d 3 during weaning. The LMR was similar between treatments on d 3 but increased by $44 \%$ for EW and LW on d 7, whereas the LMR of EWG remained unchanged during weaning. The postprandial serum concentration of Gln, Met, Trp, and $\beta$-hydroxybutyrate were greater for EWG than EW during weaning. Beginning step-down weaning at $35 \mathrm{~d}$ with a Gln supplement can help maintain the gut barrier function and wean dairy calves with a satisfactory CSI at 7 wk of age without affecting postweaning growth.

Key words: intestinal permeability, lactulose, lipopolysaccharide-binding protein, methionine

\section{INTRODUCTION}

Early weaning is considered a promising way to decrease the cost of raising dairy heifer calves (Owen and Larson, 1982). However, weaning-associated stresses can adversely affect calf's health and wellbeing (Weary et al., 2008; Hulbert and Moisá, 2016). Therefore, determining the optimum age and most appropriate weaning method is a critical decision in calf management. The Bovine Alliance on Management and Nutrition $(\mathrm{BAMN})$ recommends weaning when dairy calves consume 0.9 to $1.4 \mathrm{~kg} / \mathrm{d}$ of calf starter over at least 2 consecutive days (BAMN, 2003, 2017). Nonetheless, only $22 \%$ of US dairy producers wean calves based on calf starter intake (CSI), whereas the majority of calves are simply weaned at $9 \mathrm{wk}$ of age (USDA, 2016; Urie et al., 2018). Several studies have shown a potential to wean dairy calves as early as 4 wk of age, highlighting a satisfactory ruminal development that could ensure a 
smooth transition from a liquid to a solid diet (Owen and Larson, 1982; Anderson et al., 1987; Quigley et al., 1991). However, it should be noted that calves in those studies (Owen and Larson, 1982; Anderson et al., 1987; Quigley et al., 1991) consumed less milk $(\sim 4.0 \mathrm{~kg} / \mathrm{d})$ and more calf starter, potentially leading to accelerated ruminal development (Khan et al., 2007; Khan et al., 2016). Over the past 2 decades, there has been an increased interest in feeding high volumes of milk or milk replacer to dairy calves as data highlight positive relationships of preweaning nutrition with the growth and welfare of young heifer calves and their future milk production (Diaz et al., 2001; Soberon et al., 2012). A recent survey indicates that $31 \%$ of dairy calves in the United States receive $7.5 \mathrm{~kg}$ of milk or milk replacer per day (USDA, 2016). Calves on high planes of nutrition can encounter a significant decline in dietary nutrient supply as they increase CSI at a slow rate at weaning (Cowles et al., 2006). The reduced nutrient supply demands certain metabolic adjustments that can adversely affect the growth and wellbeing of calves, particularly when weaning is abrupt (de Passillé et al., 2011; Khan et al., 2011; Le Floc'h et al., 2014). Therefore, step-down weaning schemes are recommended to promote CSI to mitigate the nutritional stresses at weaning (Khan et al., 2007). Nonetheless, Eckert et al. (2015) observed a postweaning growth slump of dairy calves, initiating a step-down weaning scheme at $35 \mathrm{~d}$ versus $49 \mathrm{~d}$, suggesting a need for an improved understanding of interactions between age and nutrition at weaning.

As shown in piglets (Smith et al., 2010) and calves (Wood et al., 2015), weaning can impair the intestinal mucosal barrier function that precludes the translocation of pathogens and toxins from the intestinal lumen to the blood (Turner, 2009). The compromised intestinal barrier function is associated with inflammation and immune activation, which is unfavorable to the growth and wellbeing of the animals (Moeser et al., 2007; Moeser et al., 2017). Moeser et al. (2007) highlights the importance of optimizing nutrition and the immune status to help animals cope with weaning stresses. In this regard, the supplementation of Gln, a NEAA, has shown promising results in mice (Rogero et al., 2011; Sellmann et al., 2015) and pigs (Lee et al., 2003; Hsu et al., 2012). Moreover, Duttlinger et al. (2020) demonstrated a potential to replace antibiotics with Gln to alleviate weaning and transportation stresses. Data on weaning piglets indicate that Gln can positively affect intestinal health and development by improving the intestinal barrier function (Potsic et al., 2002; Qin et al., 2018), mitigating intestinal atrophy (Wu et al., 1996), and optimizing the redox status of the epithelium (Degroote et al., 2020). Because the physiology of neonatal calves is close to piglets, and van Keulen et al. (2020) showed improved intestinal morphology for a Gln supplement in preweaning calves, similar effects of Gln on gut health can be assumed for weaning calves. We hypothesized that supplementing Gln would improve paracellular permeability of the intestinal epithelium (PPE) of calves being weaned from a high volume of milk $(\geq 8.0 \mathrm{~kg} / \mathrm{d})$ at an early age and ensure similar postweaning growth compared with calves weaned at a later age without Gln supplementation. The study objective was to examine the effect of beginning a step-down weaning scheme with or without Gln at $35 \mathrm{~d}$ of age on CSI, growth, and PPE of dairy calves fed a high allowance of milk $(9.0 \mathrm{~kg} / \mathrm{d})$ compared with the responses of calves beginning the same weaning scheme without Gln at a later age of $49 \mathrm{~d}$.

\section{MATERIALS AND METHODS}

\section{Animals and Treatments}

All experimental procedures were approved by the Animal Care and Use Committee at Iowa State University (IACUC\# 18-163). The experiment was conducted at the Dairy Research and Teaching Farm at Iowa State University (Ames, IA). Thirty-six Holstein heifer calves at $28 \mathrm{~d}$ of age were matched for the week they were born and parity of the dam, and assigned randomly to 3 treatments involving a step-down weaning scheme (n $=12$ ). The treatments were as follows: (1) initiating weaning at $49 \mathrm{~d}$ of age $(\mathbf{L W}),(2)$ initiating weaning at $35 \mathrm{~d}$ of age $(\mathbf{E W})$, and (3) initiating weaning at $35 \mathrm{~d}$ with a Gln supplement (EWG). The sample size was determined with a power analysis (power $=0.80$ and $\alpha=0.05)$ targeting the statistical power to capture 1 standard deviation change in ADG and CSI of dairy heifer calves using data from Wickramasinghe et al. (2019). Calves were bottle-fed daily $9.0 \mathrm{~kg}$ of pasteurized waste milk 3 times per day $(3.0 \mathrm{~kg}$ per feeding at 0600, 1400, and $2200 \mathrm{~h}$ ) until weaning was initiated by abruptly decreasing the milk volume to $3.0 \mathrm{~kg} / \mathrm{d}$ on d 35 or 49 , depending on the treatment. That $3.0 \mathrm{~kg}$ of milk was fed at the $2200 \mathrm{~h}$ feeding until calves were weaned completely. The weaning was completed once a calf consumed $\geq 1.0 \mathrm{~kg}$ of calf starter (as-fed basis) over 2 consecutive days (BAMN, 2003, 2017). In this paper, we use the terms "preweaning," "during weaning," and "postweaning" to describe the period before restricting milk, the period from the milk restriction to the completion of weaning, and the period after the completion of weaning, respectively. L-Glutamine (Ajinomoto Health and Nutrition North America, Inc.) at $2.0 \%$ of daily 
DMI was fed in milk (3.0 $\mathrm{kg}$ at $2200 \mathrm{~h}$ ) during the last week preweaning $(28-35 \mathrm{~d})$ and the first week during weaning (35-42 d). The Gln dose was determined based on milk solids and DM in CSI and was added into the pasteurized milk $\left(\sim 40^{\circ} \mathrm{C}\right)$ in bottles. The bottles were shaken thoroughly for about $20 \mathrm{~s}$ to dissolve Gln before offering to calves. The dose at $2.0 \%$ of DMI was chosen by considering the improvements in feed efficiency, health status, and intestinal barrier function shown in weaning piglets fed similar doses (Lee et al., 2003; Hsu et al., 2012; Qin et al., 2018). All calves were housed in individual pens inside the Calf Unit of Dairy Research and Teaching Farm at Iowa State University and were bedded with straw (floor area $=1.2 \mathrm{~m} \times 1.8 \mathrm{~m}$ ). In addition, they all had access to ad libitum amounts of drinking water and a texturized calf starter with whole corn grain (Vita Plus Corp.) throughout the study. A representative sample of calf starter was analyzed for $\mathrm{DM}$, ether extract, ADF, CP (AOAC International, 2000), and NDF (Van Soest et al., 1991) at Cumberland Valley Analytical Services (Waynesboro, PA). Accordingly, the calf starter contained $90.2 \%$ of DM, and $24.0,3.9,20.2$, and $12.8 \%$ of $\mathrm{CP}$, crude fat, NDF, and $\mathrm{ADF}$, respectively.

\section{Measurements and Sample Collection}

Body weight, heart girth, hip height $(\mathbf{H H})$, hip width, and body length were measured weekly by the same person immediately before the evening $(2200 \mathrm{~h})$ feeding. Ambient temperature $\left({ }^{\circ} \mathrm{C}\right)$ and relative humidity at each pen was recorded daily using temperature loggers (Lascar Electronics Inc.). The weight of milk, calf starter, and drinking water offered and leftover were recorded daily. Paracellular permeability of the intestinal epithelium was determined by measuring the ratio of lactulose and mannitol in the blood (LMR) according to the method described in Araujo et al. (2015). Lactulose (Alfa Aesar) and D-mannitol (Acros Organics) at 0.36 and $0.09 \mathrm{~g} / \mathrm{kg}$ of $\mathrm{BW}$, respectively, were dissolved in milk (3.0 kg at $2200 \mathrm{~h}$ feeding) and fed to calves on the last day preweaning, and 3 and 7 $\mathrm{d}$ after weaning was initiated by restricting the milk volume. Those days corresponded to 35, 38, and 42 $\mathrm{d}$ of age for EW and EWG, and 49, 52, and $56 \mathrm{~d}$ of age for LW, respectively. In compliance with Araujo et al. (2015), blood was drawn from the jugular vein $1.0 \mathrm{~h}$ after feeding the sugar markers. The serum was separated by centrifuging at $2,000 \times g$ at $4^{\circ} \mathrm{C}$ for $20 \mathrm{~min}$ and stored at $-20^{\circ} \mathrm{C}$ until analysis of lactose and mannitol concentrations. Extra blood was collected, and serum or plasma was harvested with similar conditions for analysis of serum haptoglobin (HPT) and plasma LPS-binding protein (LBP) concentrations. Milk solid consumption was determined assuming $87 \%$ moisture in whole milk (Winchester and Morris, 1956).

\section{Analyses of Serum Haptoglobin and Plasma LPS-Binding Protein Concentrations}

HPT. Serum HPT concentration was measured using a commercial kit (Life Diagnostics Inc., catalog\# HAPT-11) in accordance with the manufacture's protocol. Briefly, serum samples were diluted (1:50) first with the diluent of the kit. The diluted samples and the standards $(100 \mu \mathrm{L})$ were transferred in duplicate to a 96-well plate that was then incubated on an orbital shaker $(150 \mathrm{rpm})$ at room temperature for $45 \mathrm{~min}$. After washing 5 times with the wash solution of the kit, 100 $\mu \mathrm{L}$ of a horseradish peroxidase conjugate was added into each well and incubated on the orbital shaker (150 $\mathrm{rpm}$ ) at room temperature for $45 \mathrm{~min}$. After washing as described above, $100 \mu \mathrm{L}$ of tetramethylbenzidine substrate was dispensed into each well and the plate was incubated on the orbital shaker $(150 \mathrm{rpm})$ at room temperature for $20 \mathrm{~min}$. Immediately after adding the stop solution of the kit to each well, the optical density was read at $450 \mathrm{~nm}$ using an Eon microplate spectrophotometer (BioTek Instruments, Inc.). The samples were reanalyzed if the coefficient of variation $(\mathbf{C V})$ across duplicates was $>20 \%$. The intra-assay CV of $93 \%$ of the samples were $<10 \%$, and the rest had $\mathrm{CV}<20 \%$. The interassay $\mathrm{CV}$ was $<14 \%$.

$\boldsymbol{L B P}$. Plasma LBP concentration was measured using a commercial kit (Hycult Biotech Inc., catalog\# HK503) by following the manufacture's protocol. Briefly, plasma samples were diluted (1:250) first with the diluent of the kit. The diluted samples and the standards $(100 \mu \mathrm{L})$ were transferred in duplicate into a 96-well plate that was incubated then at room temperature for $1 \mathrm{~h}$. After washing each well 4 times with the wash buffer of the kit, $100 \mu \mathrm{L}$ of the biotinylated tracer was added to each well, and then the plate was incubated at room temperature for another $1 \mathrm{~h}$. The washing was repeated as detailed above, and $100 \mu \mathrm{L}$ of diluted streptavidin-peroxidase was added to each well. The plate was incubated again at room temperature for $1 \mathrm{~h}$. After repeating the same washing steps, $100 \mu \mathrm{L}$ of tetramethylbenzidine substrate was added to each well, and the plate was incubated at room temperature in the dark for $30 \mathrm{~min}$. Immediately after the stop solution of the kit was added to each well, the optical density was read at $450 \mathrm{~nm}$ using an Eon microplate spectrophotometer (BioTek Instruments, Inc.). The samples were reanalyzed if the CV across duplicates was $>20 \%$. The intra-assay CV of $89 \%$ of the samples were $<10 \%$, whereas the rest had $\mathrm{CV}<20 \%$. The interassay CV was $<11 \%$. 


\section{Analyses of Lactulose, Mannitol, and Other Metabolites in Blood}

Determination of serum lactulose and mannitol concentrations and other serum metabolites such as AA, glucose, BHB, and urea were performed by GC-MS at the W. M. Keck Metabolomics Research Laboratory at Iowa State University (Ames, IA). Briefly, ribitol (10 $\mu \mathrm{L}$ from $1 \mathrm{mg} / \mathrm{mL}$ stock) was added to $100 \mu \mathrm{L}$ of each serum sample as an internal standard for polar compounds (e.g., lactulose and mannitol). On the other hand, $10 \mu \mathrm{L}$ of nonadecanoic acid $(1 \mathrm{mg} / \mathrm{mL})$ was added to the same serum sample as an internal standard for nonpolar compounds. After adding $0.9 \mathrm{~mL}$ of methanol (8:2 MeOH: $\mathrm{H}_{2} \mathrm{O}$ ), the serum samples for both polar and nonpolar compound analyses were incubated for $10 \mathrm{~min}$ on ice, followed by a 10-min sonication in an ice-cold water bath. The samples were then centrifuged for $7 \mathrm{~min}$ at $4^{\circ} \mathrm{C}$ and $13,000 \times g$, and $500 \mu \mathrm{L}$ of the supernatant was transferred into GC-MS vials and dried in a speedvac concentrator (Savant SpeedVac SPD120 Vacuum Concentrator, Thermo Fisher Scientific) overnight. Next, we added $50 \mu \mathrm{L}$ of methoxyamine hydrochloride $(20 \mathrm{mg} / \mathrm{mL}$ of pyridine) and incubated the samples at $30^{\circ} \mathrm{C}$ for $1.5 \mathrm{~h}$. Trimethylsilylation was then performed by incubating samples with $70 \mu \mathrm{L}$ of bis-trimethyl silyl trifluoroacetamide containing $1 \%$ trimethylchlorosilane for $30 \mathrm{~min}$ at $60^{\circ} \mathrm{C}$. The GC-MS analyses were performed for $1 \mu \mathrm{L}$ of the sample using an Agilent $6890 \mathrm{~N}$ GC coupled to a mass selective detector (model 5975, Agilent Technologies). The column used was 5\% phenyl methyl siloxane with $30 \mathrm{~m} \times 250 \mu \mathrm{m} \times 0.25 \mu \mathrm{m}$ film thickness (Agilent 19091S-433, Agilent Technologies). The oven temperature was increased first from 50 to $245^{\circ} \mathrm{C}$ at a rate of $5^{\circ} \mathrm{C} / \mathrm{min}$, and then to $320^{\circ} \mathrm{C}$ at a rate of $20^{\circ} \mathrm{C} / \mathrm{min}$. Helium was used as a carrier gas at an initial flow rate of $1.2 \mathrm{~mL} / \mathrm{min}$. The quantifications were performed using electron ionization at $70 \mathrm{eV}$ by setting the source and quadrupole temperatures at $230^{\circ} \mathrm{C}$ and $150^{\circ} \mathrm{C}$, respectively. The mass data were collected in the range from $m / z 50$ to $m / z$ 800. Agilent Enhanced ChemStation version D.02.00.275 was used for the identification of compounds. The abundance of compounds was quantified by integrating the corresponding peak areas relative to the area of the internal standards.

\section{Statistical Analysis}

Treatment effects on the responses of interest were determined using the following statistical model:

$$
\begin{aligned}
\mathrm{Y}_{\mathrm{ijkl}}=\mu & +\mathrm{T}_{\mathrm{i}}+\mathrm{PR}_{\mathrm{j}}+\mathrm{P}_{\mathrm{k}}+(\mathrm{T} \times \mathrm{PR})_{\mathrm{ij}} \\
& +\mathrm{TMP}_{\mathrm{ijkl}}+\mathrm{C}_{\mathrm{l}}+\mathrm{e}_{\mathrm{ijk} \mathrm{k}},
\end{aligned}
$$

where $Y_{\mathrm{ijkl}}=$ the response variable of interest, $\mu=$ the overall mean of the response, $\mathrm{T}_{\mathrm{i}}=$ the fixed effect of the ith treatment $(\mathrm{i}=\mathrm{LW}, \mathrm{EW}$, and $\mathrm{EWG}), \mathrm{PR}_{\mathrm{j}}=$ the fixed effect of the $\mathrm{jth}$ period $(\mathrm{j}=$ preweaning, during weaning, and postweaning), $\mathrm{P}_{\mathrm{k}}=$ the fixed effect of kth parity $(\mathrm{k}=$ primiparous and multiparous $),(\mathrm{T} \times$ $\mathrm{PR})_{\mathrm{ij}}=$ the fixed effect of the interaction between ith treatment and jth period, $\mathrm{TMP}_{\mathrm{ijk}}=$ fixed covariate effect of the average ambient temperature of the day the response was measured, $\mathrm{C}_{1}=$ the random effect of the lth calf, and $\mathrm{e}_{\mathrm{ijk} \mathrm{k}}=$ the random error assumed to be independent and identically distributed from a normal distribution with a mean of 0 and a variance of $\sigma^{2}\left[\sim N\left(\mathbf{0}, \mathbf{I} \sigma^{2}\right)\right]$. When growth performance was analyzed, the model included birth weight as a covariate. The preweaning and weaning periods corresponded to different windows of age for LW versus EW and EWG. On the other hand, postweaning performance corresponded to ages of 10 and $20 \mathrm{wk}$, common for all calves. Because ambient temperature explained much of the variability among sampling days that were different for calves at a given age, it was included in the model instead of week that calves were born. All analyses were performed using the MIXED procedure of SAS (version 9.4, SAS Institute Inc.) with the REPEATED option and the unstructured variance-covariance structure. The treatment means were compared using the Tukey-Kramer adjustment test. The $P$-value for treatment effect within a given period was obtained with the SLICE option included in the lsmeans statement. Statistical differences were declared at $P \leq 0.05$, and a tendency toward significance was considered at $0.05<P \leq 0.10$.

\section{RESULTS}

\section{Intake and Growth}

Treatment effects on nutrient intake and growth during preweaning, weaning, and postweaning are presented in Tables 1 and 2, respectively. The CSI and BW changing with age across the periods are presented in Figure 1. Calves in all 3 treatments had similar milk intake at $8.51 \mathrm{~kg} / \mathrm{d}(P=0.140)$, which was the sole contributor to DMI because CSI was negligible preweaning (Table $1)$. There was a significant treatment $\times$ period interaction on CSI and drinking water intake $(P<0.001$, data not shown). The CSI was similar among treatments preweaning $(P=0.515)$ but increased and decreased for LW compared with EW during weaning $(P<0.001)$ and postweaning $(P=0.006)$, respectively. In line with CSI, drinking water intake also increased and decreased for LW compared with EW during weaning $(P=0.010)$ and postweaning $(P<0.001)$, respectively. Drinking 
water intake, CSI, and DMI of EW and EWG were similar in each period $(P>0.140)$ but decreased $(P<$ $0.010)$ and increased $(P<0.055)$ for EWG compared with LW during weaning and postweaning, respectively (Table 1). Moreover, drinking water intake of EWG was less than LW $(P=0.014)$ despite the similar milk intake among calves $(P=0.140)$ preweaning. Initiation of weaning by restricting the milk allowance from 9.0 to $3.0 \mathrm{~kg} / \mathrm{d}$ increased CSI in all 3 treatments $(P<0.001$, Figure 1A). In line with the differences in CSI, LW had greater DMI than EW or EWG in the first week $(0.95$ vs. 0.53 and $0.63 \mathrm{~kg} / \mathrm{d}$ ) as well as the rest of the days $(1.00$ vs. 0.73 and $0.76 \mathrm{~kg} / \mathrm{d})$ during weaning $(P<$ 0.003 ). The LW achieved $\geq 1.0 \mathrm{~kg} / \mathrm{d}$ of CSI (as-fed basis) $11 \mathrm{~d}$ after weaning was initiated, and thus weaned completely at $60 \mathrm{~d}$ of age. In the week before and after the initiation of weaning, 25.2 and $14.4 \mathrm{~g}$ of Gln (0.41 and $0.24 \mathrm{~g} / \mathrm{kg}$ of BW) were fed to EWG, respectively (data not shown). The EWG achieved $\geq 1.0 \mathrm{~kg} / \mathrm{d}$ of CSI $16 \mathrm{~d}$ after weaning was initiated. Therefore, EWG was weaned completely at $51 \mathrm{~d}$ of age, which was $3 \mathrm{~d}$ earlier than EW that was weaned completely at $54 \mathrm{~d}$ of age $(P$ $<0.001$, Table 1).

Overall, the growth responses to treatments were consistent across the periods $(P>0.180$ for treatment $x$ period interaction, data not shown). The age differences of LW versus EW and EWG seemed to dictate treatment differences around weaning. Body weight $(68.2$ vs. 58.7 and $59.5 \mathrm{~kg}$ ) and body frame measurements of LW (49 d of age) were greater than EW and EWG (35 $\mathrm{d}$ of age $)$ at the initiation of weaning $(P<0.050$, Table 2 ). The ADG of LW tended to be greater than EW and EWG preweaning $(P=0.061)$. The LW and EWG maintained similar ADG from the last week preweaning to the first week of weaning $(P>0.650)$, whereas EW experienced a growth slump $(P=0.007)$. The ADG of EWG tended to be greater than EW $(P=0.067)$ but was similar to LW $(P=0.168)$ during the first week of weaning. Signifying again the age difference, LW had greater BW, heart girth, $\mathrm{HH}$, and hip width than both EW and EWG when measured at the end of the first week of weaning $(P<0.015$, Table 2$)$. Similarly, LW tended to have a greater BW, representing a 1.99-fold increase in birth weight compared with the BW of EW and EWG, representing 1.77- and 1.76-fold increases in birth weight at complete weaning, respectively $(P=$ 0.069, Table 2). The EW and EWG exhibited a marked recovery of growth postweaning and had BW, heart girth, HH, hip width, and body length that were similar to LW at 10 wk of age $(P>0.210$, Figure $1 \mathrm{~B}$ and Table $2)$. The BW and $\mathrm{HH}$ were also similar among the treatments at $20 \mathrm{wk}$ of age $(P>0.750$, Table 2$)$.

Table 1. Milk intake, calf starter intake (CSI), DMI (milk solid + starter DM), and drinking water intake (from buckets) of calves undergoing a step-down weaning scheme beginning at $49 \mathrm{~d}$ of age (LW) or earlier (35 d of age) with (EWG) or without (EW) an oral supplementation of Gln from 28 to $42 \mathrm{~d}$ of age $(\mathrm{n}=12)$

\begin{tabular}{|c|c|c|c|c|c|}
\hline \multirow[b]{2}{*}{ Variable } & \multicolumn{3}{|c|}{ Least squares means } & \multirow[b]{2}{*}{ SEM } & \multirow[b]{2}{*}{$P$-value } \\
\hline & LW & EW & EWG & & \\
\hline \multicolumn{6}{|l|}{ Preweaning $^{1}$} \\
\hline Milk intake, $\mathrm{kg} / \mathrm{d}$ & 8.48 & 8.58 & 8.48 & 0.05 & 0.140 \\
\hline CSI, $\mathrm{kg} / \mathrm{d}$ & 0.06 & 0.01 & 0.04 & 0.06 & 0.515 \\
\hline DMI, $\mathrm{kg} / \mathrm{d}$ & 1.08 & 1.00 & 1.04 & 0.05 & 0.518 \\
\hline Drinking water intake, $\mathrm{kg} / \mathrm{d}$ & $1.52^{\mathrm{a}}$ & $1.12^{\mathrm{ab}}$ & $0.73^{\mathrm{b}}$ & 0.19 & 0.014 \\
\hline \multicolumn{6}{|l|}{ First week of weaning ${ }^{2}$} \\
\hline Milk intake, kg/d & 2.80 & 2.79 & 2.80 & 0.09 & 0.984 \\
\hline $\mathrm{CSI}, \mathrm{kg} / \mathrm{d}$ & $0.57^{\mathrm{a}}$ & $0.23^{\mathrm{b}}$ & $0.34^{\mathrm{b}}$ & 0.05 & $<0.001$ \\
\hline DMI, $\mathrm{kg} / \mathrm{d}$ & $0.95^{\mathrm{a}}$ & $0.53^{\mathrm{b}}$ & $0.63^{\mathrm{b}}$ & 0.05 & $<0.001$ \\
\hline Drinking water intake, $\mathrm{kg} / \mathrm{d}$ & $3.14^{\mathrm{a}}$ & $2.43^{\mathrm{b}}$ & $2.77^{\mathrm{ab}}$ & 0.19 & 0.035 \\
\hline \multicolumn{6}{|l|}{ During remainder of weaning } \\
\hline CSI, $\mathrm{kg} / \mathrm{d}$ & 1.00 & 0.73 & 0.76 & 0.07 & 0.029 \\
\hline Drinking water intake, $\mathrm{kg} / \mathrm{d}$ & 3.59 & 2.52 & 2.20 & 0.18 & 0.003 \\
\hline Days to reach $1.0 \mathrm{~kg} / \mathrm{d}$ CSI & $11.0^{\mathrm{c}}$ & $18.6^{\mathrm{b}}$ & $16.0^{\mathrm{a}}$ & 0.20 & $<0.001$ \\
\hline Age when weaning completed, d & $60.0^{\mathrm{a}}$ & $53.6^{\mathrm{b}}$ & $51.0^{\mathrm{c}}$ & 0.20 & $<0.001$ \\
\hline \multicolumn{6}{|l|}{ Postweaning ${ }^{3}$} \\
\hline CSI, $\mathrm{kg} / \mathrm{d}$ & $2.55^{\mathrm{b}}$ & $2.73^{\mathrm{a}}$ & $2.83^{\mathrm{a}}$ & 0.05 & 0.001 \\
\hline Drinking water intake, $\mathrm{kg} / \mathrm{d}$ & $6.64^{\mathrm{a}}$ & $7.59^{\mathrm{b}}$ & $7.10^{\mathrm{ab}}$ & 0.17 & $<0.001$ \\
\hline
\end{tabular}




\section{Lactulose-to-Mannitol Ratio and Acute Phase Proteins in Blood}

Serum lactulose and mannitol concentrations and LMR are presented in Table 3. Figure 2A presents how LMR changed across the last day preweaning and 3 and $7 \mathrm{~d}$ after initiating weaning by restricting milk from 9.0 to $3.0 \mathrm{~kg} / \mathrm{d}$. The mannitol concentration was similar at $1.57 \mu \mathrm{g} / \mathrm{L}$ across treatments $(P=0.867)$ as well as across the days $(P=0.912)$. Serum lactulose concentration was also similar among treatments $(P=0.801)$ but tended to increase during weaning versus preweaning $(P=0.069)$. Regardless of treatments, calves had similar LMR preweaning and $3 \mathrm{~d}$ after initiating weaning (Figure 2A). Relative to d 3 values, LMR of LW and
EW increased $(P<0.040$, Figure $2 \mathrm{~A})$, whereas that of EWG remained unchanged on $\mathrm{d} 7$ during weaning. Figures $2 \mathrm{~B}$ and $\mathrm{C}$ present how serum HPT and plasma LBP concentrations changed during the first week of weaning relative to preweaning concentrations, respectively. All calves had similar serum HPT concentrations preweaning $(P>0.320$, Figure $2 \mathrm{~B})$. The HPT concentration of LW increased $3 \mathrm{~d}$ after the initiation of weaning $(P=0.030)$ and tended to remain higher on d 7 relative to preweaning concentration $(P=0.077$, Figure 2B). The serum HPT concentration of LW was greater than that of EW on d $3(P=0.025)$ and tended to be greater than that of EWG on $\mathrm{d} 7$ during weaning $(P=0.098)$. The plasma LBP concentrations of all 3 treatments increased $(P<0.001)$ compared with pre-

Table 2. Growth performance of calves undergoing a step-down weaning scheme beginning at $49 \mathrm{~d}$ of age (LW) or earlier (35 d of age) with (EWG) or without (EW) an oral supplementation of Gln from 28 to $42 \mathrm{~d}$ of age $(\mathrm{n}=12)$

\begin{tabular}{|c|c|c|c|c|c|}
\hline \multirow[b]{2}{*}{ Variable } & \multicolumn{3}{|c|}{ Least squares means } & \multirow[b]{2}{*}{ SEM } & \multirow[b]{2}{*}{$P$-value } \\
\hline & LW & EW & EWG & & \\
\hline Birth weight, $\mathrm{kg}$ & 37.7 & 38.0 & 38.1 & 0.4 & 0.780 \\
\hline \multicolumn{6}{|l|}{ Preweaning $^{1}{ }^{-\mathrm{Ng}_{\mathrm{S}}}$} \\
\hline $\mathrm{BW}, \mathrm{kg}$ & $68.2^{\mathrm{a}}$ & $58.7^{\mathrm{b}}$ & $59.5^{\mathrm{b}}$ & 3.2 & 0.040 \\
\hline Heart girth, $\mathrm{cm}$ & $88.5^{\mathrm{a}}$ & $86.5^{\mathrm{b}}$ & $86.6^{\mathrm{b}}$ & 0.5 & $<0.001$ \\
\hline Hip height, cm & $87.4^{\mathrm{a}}$ & $85.3^{\mathrm{b}}$ & $85.5^{\mathrm{b}}$ & 0.5 & $<0.001$ \\
\hline Hip width, cm & $20.8^{\mathrm{a}}$ & $20.2^{\mathrm{b}}$ & $20.5^{\mathrm{ab}}$ & 0.2 & 0.027 \\
\hline Body length, cm & $79.7^{\mathrm{a}}$ & $77.2^{\mathrm{b}}$ & $77.1^{\mathrm{b}}$ & 0.5 & $<0.001$ \\
\hline $\mathrm{ADG}, \mathrm{kg} / \mathrm{d}$ & 0.66 & 0.50 & 0.42 & 0.09 & 0.061 \\
\hline \multicolumn{6}{|l|}{ First week of weaning ${ }^{2}$} \\
\hline $\mathrm{BW}, \mathrm{kg}$ & $72.4^{\mathrm{a}}$ & $59.5^{\mathrm{b}}$ & $62.0^{\mathrm{b}}$ & 3.0 & 0.003 \\
\hline Heart girth, $\mathrm{cm}$ & $90.9^{\mathrm{a}}$ & $87.1^{\mathrm{b}}$ & $87.6^{\mathrm{b}}$ & 0.8 & 0.011 \\
\hline Hip height, cm & $91.2^{\mathrm{a}}$ & $87.6^{\mathrm{b}}$ & $88.6^{\mathrm{b}}$ & 0.8 & 0.010 \\
\hline Hip width, cm & $22.1^{\mathrm{a}}$ & $20.7^{\mathrm{b}}$ & $21.5^{\mathrm{ab}}$ & 0.3 & 0.006 \\
\hline Body length, cm & $83.5^{\mathrm{a}}$ & $80.8^{\mathrm{b}}$ & $80.1^{\mathrm{b}}$ & 0.9 & 0.052 \\
\hline $\mathrm{ADG}, \mathrm{kg} / \mathrm{d}$ & $0.47^{\mathrm{a}}$ & $0.03^{\mathrm{b}}$ & $0.25^{\mathrm{ab}}$ & 0.11 & 0.005 \\
\hline \multicolumn{6}{|c|}{ During remainder of weaning ${ }^{3}$} \\
\hline $\mathrm{ADG}, \mathrm{kg} / \mathrm{d}$ & 0.94 & 0.83 & 0.79 & 0.12 & 0.493 \\
\hline BW at complete weaning & 74.8 & 66.5 & 66.4 & 3.1 & 0.064 \\
\hline BW:birth weight ${ }^{4}$ & 1.99 & 1.77 & 1.76 & 0.08 & 0.069 \\
\hline \multicolumn{6}{|l|}{ Postweaning } \\
\hline \multicolumn{6}{|l|}{10 wk of age ${ }^{5}$} \\
\hline BW, kg & 88.5 & 87.6 & 89.7 & 3.0 & 0.871 \\
\hline Heart girth, $\mathrm{cm}$ & 97.6 & 97.5 & 96.4 & 0.7 & 0.314 \\
\hline Hip height, cm & 94.3 & 93.7 & 94.4 & 0.6 & 0.669 \\
\hline Hip width, cm & 24.6 & 24.4 & 24.7 & 0.2 & 0.673 \\
\hline Body length, cm & 89.0 & 89.1 & 90.6 & 0.7 & 0.211 \\
\hline $\mathrm{ADG}, \mathrm{kg} / \mathrm{d}$ & 1.11 & 0.92 & 1.18 & 0.11 & 0.188 \\
\hline \multicolumn{6}{|l|}{20 wk of age } \\
\hline $\mathrm{BW}, \mathrm{kg}$ & 165.4 & 166.4 & 161.1 & 10.0 & 0.908 \\
\hline Hip height, $\mathrm{cm}$ & 109.9 & 109.0 & 109.7 & 1.1 & 0.775 \\
\hline
\end{tabular}

${ }^{\mathrm{a}, \mathrm{b}}$ Least squares means with different superscripts indicate significant difference $(P<0.050)$.

${ }^{1} \mathrm{BW}$ and body frame measurements at $49 \mathrm{~d}$ for $\mathrm{LW}$ and $35 \mathrm{~d}$ for EW and EWG. ADG was during 42 to $49 \mathrm{~d}$ for LW and 28-35 d for EW and EWG.

${ }^{2} \mathrm{BW}$ and body frame measurements at $56 \mathrm{~d}$ for $\mathrm{LW}$ and $42 \mathrm{~d}$ for EW and EWG. ADG was during 49 to $56 \mathrm{~d}$ for LW and 35 to $42 \mathrm{~d}$ for EW and EWG.

${ }^{3} \mathrm{BW}$ and body frame measurements at 60,54 , and $51 \mathrm{~d}$ for $\mathrm{LW}$, EW, and EWG, respectively.

${ }^{4}$ The ratio between BW at weaning and birth weight.

${ }^{5} \mathrm{BW}$ and body frame measurements at $70 \mathrm{~d}$ for all treatments. The ADG was during 63 to $70 \mathrm{~d}$ for all treatments. 

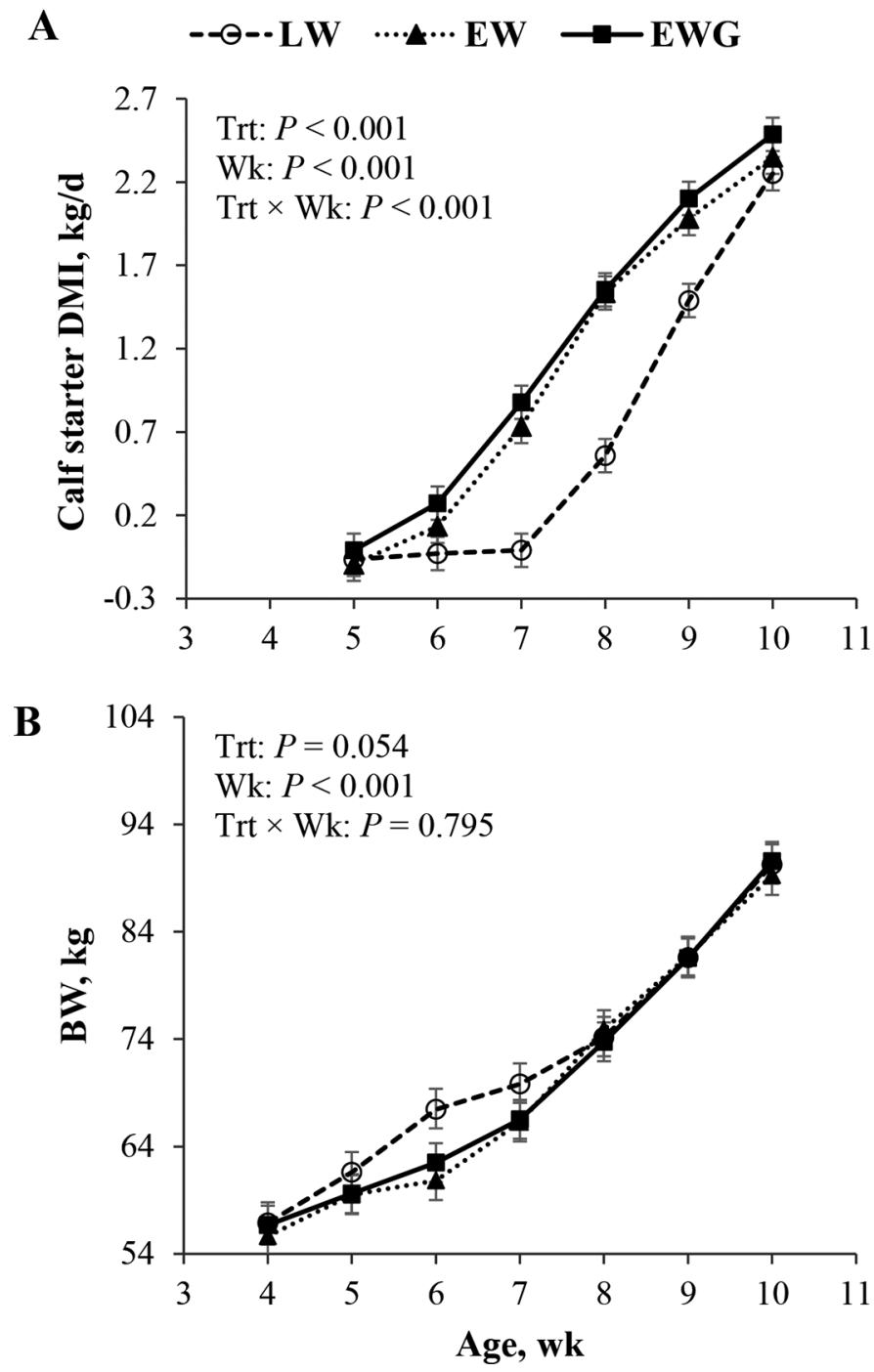

Figure 1. Weekly mean ( \pm SEM) for calf starter DMI $(A)$, and BW (B) of calves undergoing a step-down weaning scheme that was initiated by restricting the milk volume at $49 \mathrm{~d}$ of age (LW) or earlier (35 d of age) with (EWG) or without (EW) an oral supplementation of Gln from 28 to $42 \mathrm{~d}$ of age $(\mathrm{n}=12)$. All calves were weaned completely once they achieved $1.0 \mathrm{~kg} / \mathrm{d}$ of calf starter intake over 2 consecutive days. Trt $=$ treatment; $\mathrm{Wk}=$ week.

weaning concentrations (Figure 2C), but EW tended to be associated with lower plasma LBP than LW and EWG $(P=0.082) 3 \mathrm{~d}$ after the initiation of weaning. The LBP concentrations in all 3 groups had returned to preweaning concentrations $7 \mathrm{~d}$ after the initiation of weaning.

\section{Postprandial Serum Concentrations of Metabolites}

Postprandial serum concentrations of AA, glucose, $\mathrm{BHB}$, and urea preweaning and in the first week during weaning are presented in Table 3 . Changes in the concentrations of some of those metabolites during the first week of weaning relative to preweaning concentrations are presented in Figure 3. The concentrations of all metabolites except Ile and Gly $(P<0.035$ for treatment $\times$ period interaction, data not shown) responded consistently to treatments before and during weaning. The serum Gln concentration of EWG was greater than EW and LW preweaning $(P<0.010)$ and during the first week of weaning $(P<0.020)$. Relative to preweaning concentrations, serum Gln concentration of EWG decreased by $32 \%$ in the first week during weaning $(P$ $=0.009$, Figure $3 \mathrm{~A})$. The concentration of total serum $\mathrm{EAA}(\mathrm{Ile}+\mathrm{Leu}+\mathrm{Lys}+$ Met + Phe + Thr + Trp + Val) was greater in LW $(P=0.041)$ and EWG $(P=$ $0.007)$ than EW preweaning. However, the concentration of total serum EAA was similar among treatments in the first week during weaning $(P=0.239$, Figure $3 \mathrm{~B})$. The concentrations of total serum branched-chain AA, including Ile, Leu, and Val, were greater in EWG than EW preweaning $(P<0.035$, Figure 3C). Similarly, the Phe concentration of LW was greater than EW $(P$ $=0.022)$ but not different from EWG $(P=0.766)$ preweaning (Figure 3D). However, none of those EAA concentrations were different between treatments during weaning $(P>0.102$, Table 3$)$. On the other hand, serum Met of EWG was greater than EW preweaning as well as during the first week of weaning $(P<0.020$, Figure 3E). Serum Met concentration of EWG was even greater than that of LW preweaning $(P=0.010$, Table 3). Postprandial serum glucose concentration was not affected by treatments but tended to be greater for EWG versus EW preweaning $(P=0.091$, Table 3$)$. The EWG had greater serum urea concentrations than EW preweaning $(P=0.020)$, but the Gln supplementation did not change the serum urea concentration during the first week of weaning. Regardless of treatments, serum BHB increased $(P<0.001)$ once weaning was initiated by restricting the milk allowance (Figure $3 \mathrm{~F}$ ). The LW calves had greater serum BHB concentrations than EW during the first week of weaning $(P=0.018)$.

\section{DISCUSSION}

To ensure less stressful weaning and to mitigate potential growth slumps, step-down weaning schemes are recommended over abrupt weaning (Khan et al., 2007), particularly for dairy calves that are fed high volumes of milk or milk replacer (Steele et al., 2017). Eckert et al. (2015) used a step-down scheme to compare weaning from a high milk replacer allowance at 42 versus $56 \mathrm{~d}$ of age. They initiated the scheme by decreasing milk replacer allowance by $50 \%(4.0$ vs. $8.0 \mathrm{~L} / \mathrm{d})$ at 35 or 49 $\mathrm{d}$ of age and weaned calves completely $7 \mathrm{~d}$ later. In the present study, we initiated step-down weaning with a 
Table 3. Postprandial $(1 \mathrm{~h})$ serum metabolite concentrations of calves undergoing a step-down weaning scheme beginning at $49 \mathrm{~d}$ of age (LW) or earlier (35 d of age) with (EWG) or without (EW) an oral supplementation of Gln from 28 to $42 \mathrm{~d}$ of age $(\mathrm{n}=12)$

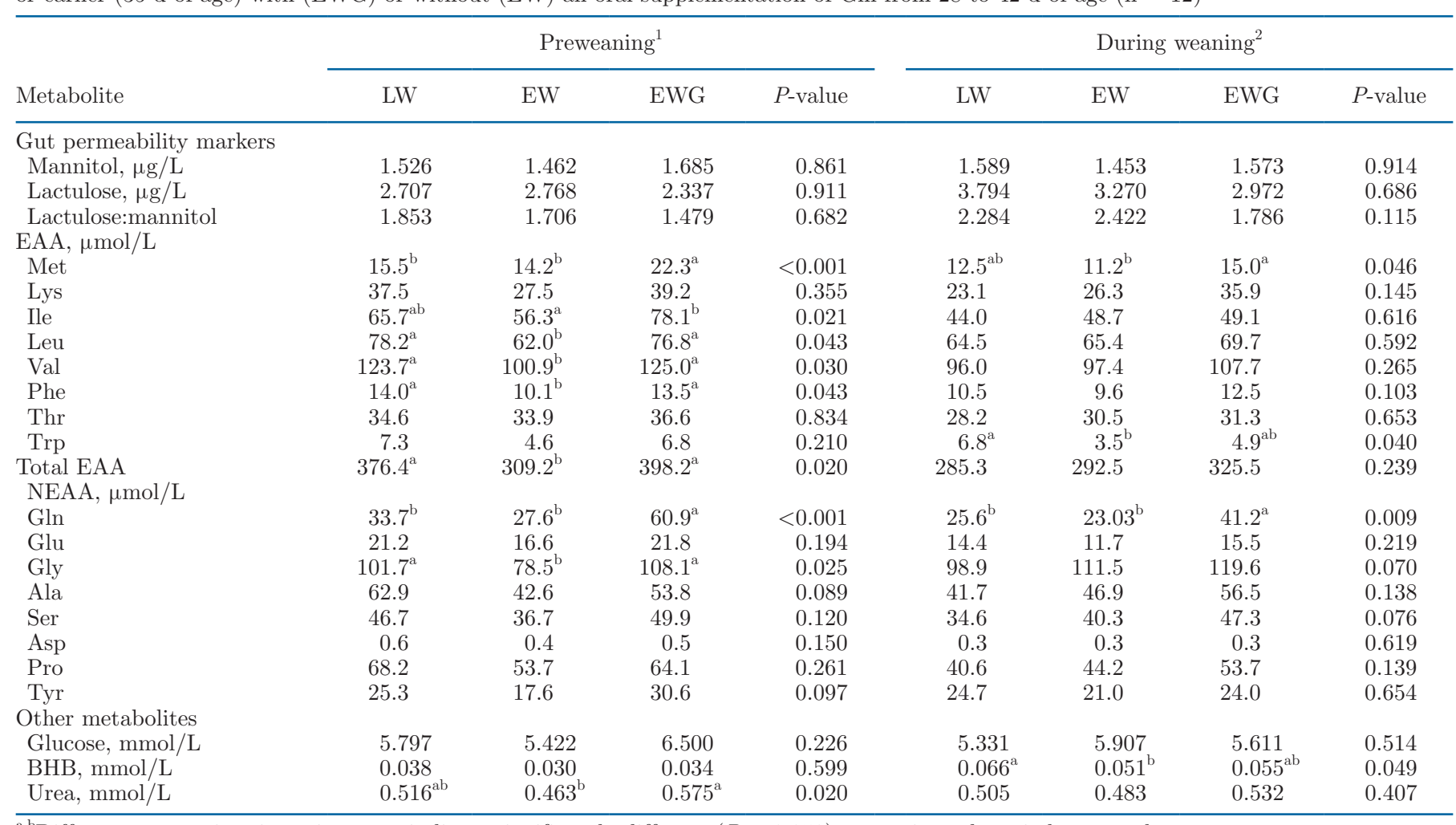

${ }^{\mathrm{a}, \mathrm{b}}$ Different superscripts in a given row indicate significantly different $(P<0.050)$ means in each period separately.

${ }^{1}$ One day before weaning began (at $34 \mathrm{~d}$ for EW and EWG, and $48 \mathrm{~d}$ for LW).

${ }^{2}$ Two days during the first week of weaning (38 and $42 \mathrm{~d}$ for EW and EWG, and 52 and $56 \mathrm{~d}$ for LW).

more severe decrease $(67 \%)$ in milk volume $(9.0$ to 3.0 $\mathrm{kg} / \mathrm{d})$ at the same ages. Moreover, we continued with the $3.0 \mathrm{~kg} / \mathrm{d}$ of milk until calves achieved a $1.0 \mathrm{~kg} / \mathrm{d}$ of CSI to wean them completely. Calves in the present study had a negligible CSI when receiving the full milk allowance, testifying the negative relationship between liquid diet allowance and CSI (Leaver and Yarrow, 1972; de Passillé and Rushen, 2012; Hill et al., 2012). Once the milk allowance was restricted, CSI increased in both EW and LW, but remained fairly low $(<0.30$ $\mathrm{kg} / \mathrm{d}$ ) for $\mathrm{EW}$ in the first week during weaning. The high milk allowance seemed to play a role in determining the CSI independent of age as calves weaned from a lower milk replacer allowance $(5.4 \mathrm{~L} / \mathrm{d}$ of milk replacer with $14.7 \%$ solid) at $35 \mathrm{~d}$ consumed $>1.0 \mathrm{~kg} / \mathrm{d}$ of calf starter during the first week after weaning in Jaeger et al. (2020). Owing to $0.60 \mathrm{~kg} / \mathrm{d}$ of CSI, LW was able to maintain a constant DMI, whereas EW encountered a significant DMI decline that compromised its ADG during the first week of weaning. The lower CSI of EW most probably suggested a lack of ruminal development at 35 versus $49 \mathrm{~d}$ of age (Khan et al., 2011). The literature emphasizes that a successful transition from liquid to solid diets requires the physical and metabolic development of the rumen accompanied by the development of the salivary apparatus, rumination behavior, and physiological adjustments of other tissues (Baldwin et al., 2004; Khan et al., 2011). However, the metabolic development of ruminal epithelium seems similar at 35 and $49 \mathrm{~d}$ of age as serum BHB were comparable between EW and LW preweaning. Although LW increased CSI faster and achieved the $1.0 \mathrm{~kg} / \mathrm{d}$ target sooner than EW (11 vs. 19 d), EW could be weaned still at an earlier age than LW (54 vs. 60 d) in the present study. Because raising preweaning calves is twice as costly as raising weaned calves (Hawkins et al., 2019, 2020), weaning 6 d earlier can be economically advantageous. Nonetheless, it is noteworthy that weaning schemes should be evaluated not only based on economic gains but also related to the effects on calf health and welfare and future performances (Khan et al., 2011; Soberon et al., 2012; Hulbert and Moisá, 2016).

Both EW and LW had similar BW and $\mathrm{HH}$ at 10 and 20 wk of age, indicating no adverse effect of initiating weaning with the present scheme at 35 versus $49 \mathrm{~d}$ of age on the growth postweaning, and perhaps the future 
$\mathbf{A}$

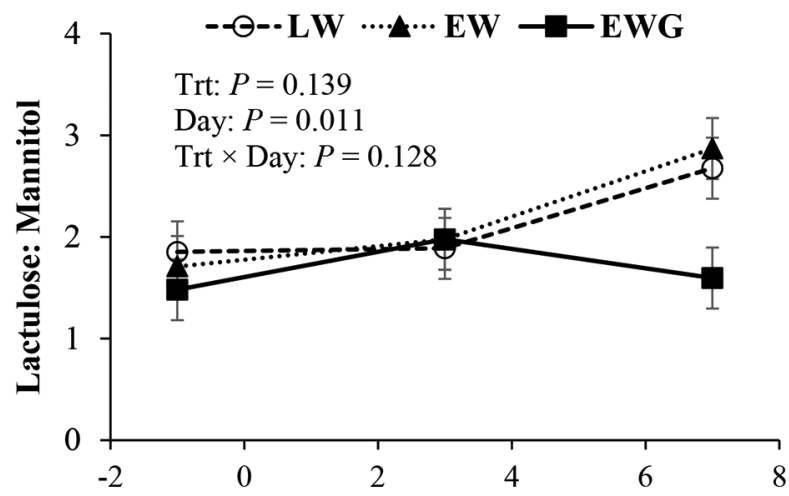

B

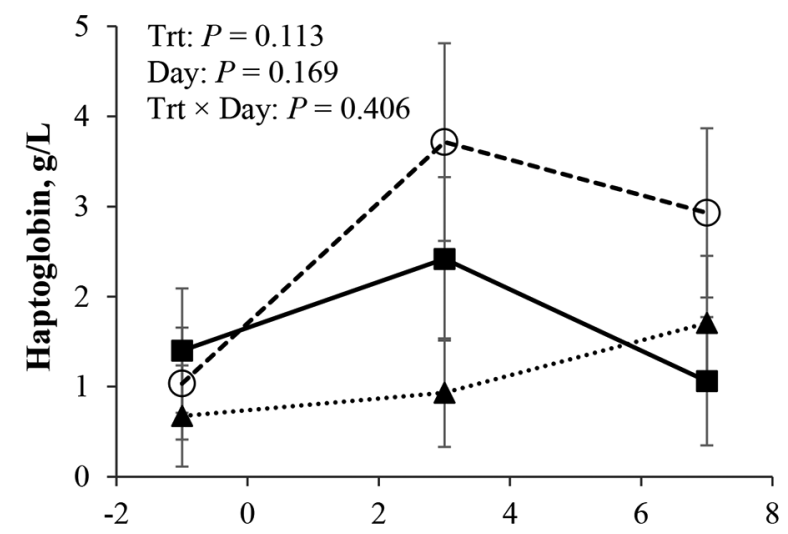

C

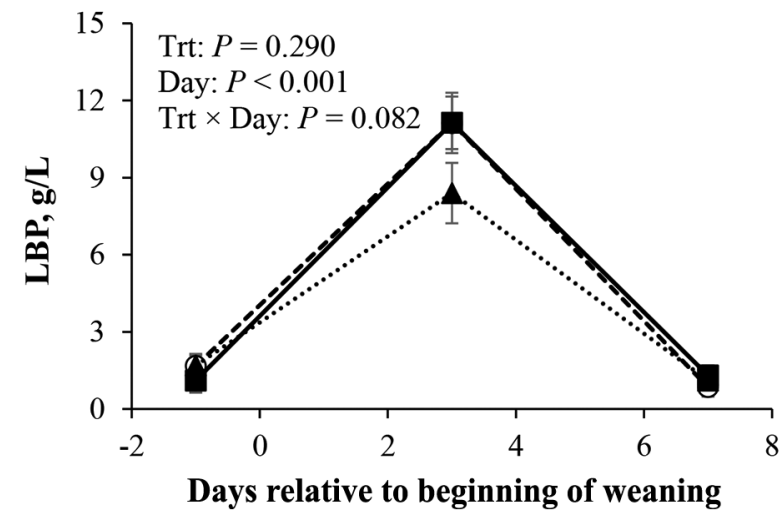

Figure 2. Least squares means \pm SEM of serum lactulose:mannitol ratio (A), serum haptoglobin (B), and plasma LPS-binding protein (LBP; C) of calves undergoing a step-down weaning scheme that was initiated by restricting the milk volume at $49 \mathrm{~d}$ of age (LW) or earlier (35 d of age) with (EWG) or without (EW) an oral supplementation of Gln from 28 to $42 \mathrm{~d}$ of age $(\mathrm{n}=12)$. Trt $=$ treatment.

milk production as well (Soberon et al., 2012). Even though calves in the EW group had a low CSI in the first week during weaning, they increased it sharply during the following week, resulting in a quick recovery from the growth slump. On the contrary, in Eckert et al. (2015), beginning weaning at 35 versus $49 \mathrm{~d}$ of age was related to a postweaning growth slump at $10 \mathrm{wk}$, albeit the early-weaned calves had achieved $>1.0 \mathrm{~kg} / \mathrm{d}$ of CSI at complete weaning (42 d of age). Perhaps, extending the duration of weaning (e.g., 14 vs. 7 d) with some volume of milk, regardless of CSI, could have mitigated such a postweaning growth slump (Pluske et al., 1996). However, a comparison between the present weaning scheme and that in Eckert et al. (2015) should acknowledge several other differences between the 2 studies such as type and nutrient composition of liquid and solid diets, health status of calves, and the season during when studies were conducted.

Despite the unaffected postweaning growth, one cannot overlook the growth slump of EW at the onset of weaning as it can reflect multiple forms of nutritional stress (e.g., inflammation and infections linked to compromised gut barrier function; Campbell et al., 2013; Khan et al., 2016; Moeser et al., 2017). The literature highlights that dietary supplements of Gln improves gut barrier function, inflammation markers, and behavior, which are related to growth improvements in piglets subjected to heat stress, transportation stress, or an LPS challenge (Johnson and Lay, 2017; Qin et al., 2018). In the present study, we demonstrated those effects of Gln could also be true in weaning calves as EWG tended to improve ADG at the onset of weaning. Because protein synthesis represents $70 \%$ of water-free empty BW gain (Bartlett et al., 2006), the improvement in ADG could be a result of protein synthesis enhanced by Gln in weaning calves (Ji et al., 2019). The supplementation of Gln seems to increase the precursor supply and the stimulatory signals of protein synthesis, as EWG had greater serum EAA (particularly branched-chain AA) concentrations than EW during weaning. One way dietary Gln could increase postprandial serum EAA is by improving the capacity of the small intestine for digestion and absorption of proteins. Supporting this notion, van Keulen et al. (2020) demonstrated improved villus heights in the duodenum and jejunum of dairy calves supplemented with Gln in milk. Among EAA responding to Gln supplementation, Met showed the most consistent increase in the serum concentrations. No data describe an association of Gln and Met, even in mature cattle, for which Met is the most limiting AA. The literature on weaning piglets, however, highlights a possibility that Gln supplementation can increase serum Met by decreasing the splanchnic clearance (Hu et al., 2012; Dong et al., 2019).

Moreover, the present study results highlighted, for the first time, the potential of Gln to improve PPE in weaning calves. The PPE is a major mechanism that contributes to the intestinal barrier function (Moeser et al., 2017), and the role of Gln in improving PPE in weaning piglets has been well studied (Ji et al., 2019). Orally administered lactulose and mannitol recovered in urine is frequently used as a noninvasive method 

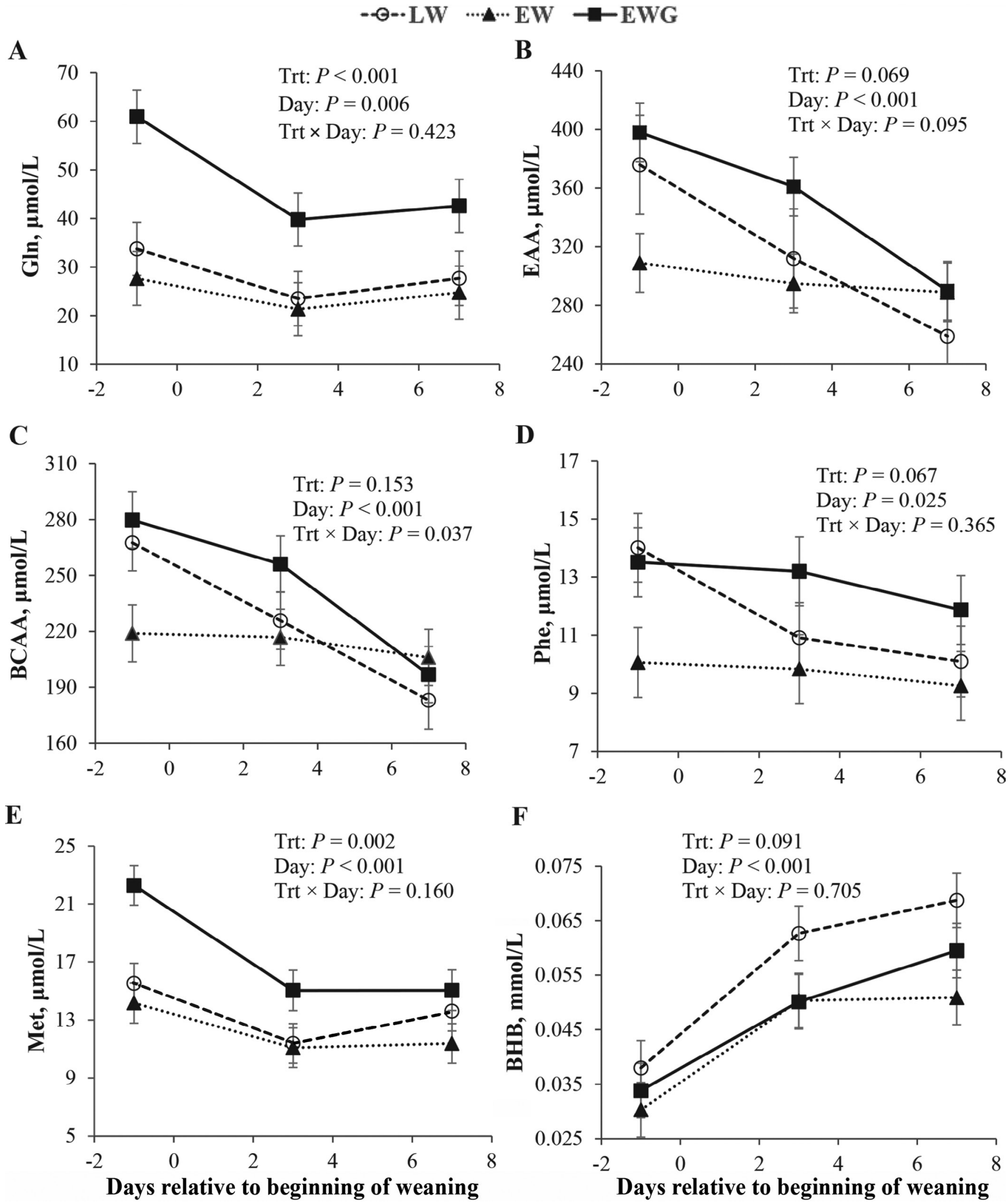

Figure 3. Least squares means \pm SEM of serum Gln (A), total EAA (B), branched-chain amino acids (BCAA; C), Phe (D), Met (E), and BHB (F) of calves undergoing a step-down weaning scheme that was imitiated by restricting the milk volume at $49 \mathrm{~d}$ of age (LW) or earlier (35 $\mathrm{d}$ of age) with $(\mathrm{EWG})$ or without $(\mathrm{EW})$ an oral supplementation of Gln from 28 to $42 \mathrm{~d}$ of age $(\mathrm{n}=12)$. Trt $=$ treatment. 
to assess PPE in humans. Elevated LMR in urine is indicative of increased PPE. Considering the challenges of obtaining representative urine samples, Fleming et al. (1996) developed a method to determine LMR in serum, which was highly correlated with LMR in urine $(\mathrm{r}=0.88)$ in humans. Araujo et al. (2015) developed a similar method to determine LMR in the blood of calves. Therefore, we used that method to assess PPE of weaning calves in the present study. Our LMR revealed that an aggressive restriction of milk can increase PPE in calves, agreeing with increased PPE observed for feed restrictions in mature cows (Kvidera et al., 2017). Our results also highlighted a lag time $(4-7 \mathrm{~d})$ for the PPE response, which is in agreement with Degroote et al. (2020). Those authors assessed PPE in the small intestine of weaned piglets and did not see a PPE increment until 5 d postweaning. Degroote et al. (2020) also showed a markedly induced oxidative damage to the intestinal mucosa that was closely in line with the PPE response for weaning. Perhaps, the Gln supplementation mitigated the potential increase in PPE by alleviating oxidative damage to the intestinal mucosa of weaning calves (Ji et al., 2019). Concerning the positive link between PPE and the likelihood of luminal LPS translocation to the bloodstream, one would expect LMR to be in line with HPT and LBP concentrations in the blood (Wright et al., 1990). Our data, however, do not show such synchrony. For instance, plasma LBP concentrations seemed to respond far more quickly to the milk volume restriction than LMR did. One potential mechanism that can create a quick surge of plasma LBP is inflammation in the intestine and corresponding production of cytokines such as IL-6 and TNF- $\alpha$ (McCracken et al., 1999; Pié et al., 2004; Kim et al., 2011), which can stimulate the production of LBP in the liver (Wolk et al., 2007). In that sense, the low plasma LBP of EW could reflect a less severe inflammation in the intestine or an inadequate immune response to the inflammation. Jafari et al. (2006) and McLamb et al. (2013) support the latter. It is also fair to mention that many commercial kits including the one used in the present study are unable to distinguish free and bound forms of LBP, limiting the ability for drawing robust conclusions on treatment effects.

\section{CONCLUSIONS}

The present study offered a step-down scheme to wean calves fed a high milk allowance $(9.0 \mathrm{~kg} / \mathrm{d})$ without affecting CSI and growth postweaning. In the present scheme, weaning was initiated at $35 \mathrm{~d}$ of age with an abrupt restriction of the milk allowance to $3.0 \mathrm{~kg} / \mathrm{d}$, and calves were weaned completely once they consumed $\geq 1.0 \mathrm{~kg} / \mathrm{d}$ of calf starter (as-fed basis). Initiating wean- ing at $35 \mathrm{~d}$ decreased ADG and was associated with a lower rate of CSI increase during weaning as opposed to initiating weaning at $49 \mathrm{~d}$. Supplementation of Gln (2.0\% of DMI) at $35 \mathrm{~d}$ tended to improve the ADG. Calves with Gln also increased CSI faster and weaned completely 3 d earlier than calves without Gln (51 vs. $54 \mathrm{~d}$ of age). Regardless of the age, the milk allowance restriction was associated with an increased PPE, suggesting an impairment of the gut barrier function. The supplementation of Gln mitigated such impairment. The present step-down scheme with a Gln supplement ( $2 \%$ of DMI) could help in weaning dairy calves from a high milk volume without compromising the growth during and postweaning.

\section{ACKNOWLEDGMENTS}

The authors gratefully acknowledge Ajinomoto Animal Nutrition North America Inc (Chicago, IL) for providing L-glutamine and funds for the blood analyses. We are thankful for the support received from the staff of calf facilities in Dairy Research and Teaching Farm at Iowa State University. We also appreciate the technical advice and support offered by the staff of W. M. Keck Metabolomics Research Laboratory at Iowa State University. The authors have not stated any conflicts of interest.

\section{REFERENCES}

Anderson, K. L., T. G. Nagaraja, and J. L. Morrill. 1987. Ruminal metabolic development in calves weaned conventionally or early. J. Dairy Sci. 70:1000-1005. https://doi.org/10.3168/jds.S0022 $-0302(87) 80105-4$.

AOAC International. 2000. Official Methods of Analysis. 17th ed. Association of Official Analytical Chemists.

Araujo, G., C. Yunta, M. Terré, A. Mereu, I. Ipharraguerre, and A. Bach. 2015. Intestinal permeability and incidence of diarrhea in newborn calves. J. Dairy Sci. 98:7309-7317. https://doi.org/10 $.3168 /$ jds.2015-9666.

Baldwin, R. L. VI, K. R. McLeod, J. L. Klotz, and R. N. Heitmann. 2004. Rumen development, intestinal growth and hepatic metabolism in the pre- and post-weaning ruminant. J. Dairy Sci. 87(ESuppl.):E55-E65.

BAMN. 2003. A guide to dairy calf feeding and management. Bovine Alliance on Management and Nutrition (BAMN). Accessed Jun. 16, 2021. https://www.aphis.usda.gov/animal_health/nahms/ dairy/downloads/bamn/BAMN03_GuideFeeding.pdf.

BAMN. 2017. A guide to dairy calf feeding and management. Bovine Alliance on Management and Nutrition (BAMN). Accessed Jun. 16, 2021. https://www.aphis.usda.gov/animal_health/nahms/ dairy/downloads/bamn/BAMN17_GuideFeeding_1.pdf.

Bartlett, K. S., F. K. McKeith, M. J. VandeHaar, G. E. Dahl, and J. K. Drackley. 2006. Growth and body composition of dairy calves fed milk replacers containing different amounts of protein at two feeding rates. J. Anim. Sci. 84:1454-1467. https://doi.org/10 $.2527 / 2006.8461454 x$.

Campbell, J. M., J. D. Crenshaw, and J. Polo. 2013. The biological stress of early weaned piglets. J. Anim. Sci. Biotechnol. 4:19. https: //doi.org/10.1186/2049-1891-4-19.

Cowles, K. E., R. A. White, N. L. Whitehouse, and P. S. Erickson. 2006. Growth characteristics of calves fed an intensified milk re- 
placer regimen with additional lactoferrin. J. Dairy Sci. 89:48354845. https://doi.org/10.3168/jds.S0022-0302(06)72532-2.

de Passillé, A. M., T. F. Borderas, and J. Rushen. 2011. Weaning age of calves fed a high milk allowance by automated feeders: Effects on feed, water, and energy intake, behavioral signs of hunger, and weight gains. J. Dairy Sci. 94:1401-1408. https://doi.org/10.3168/ jds.2010-3441.

de Passillé, A. M., and J. Rushen. 2012. Adjusting the weaning age of calves fed by automated feeders according to individual intakes of solid feed. J. Dairy Sci. 95:5292-5298. https://doi.org/10.3168/ jds.2012-5521.

Degroote, J., H. Vergauwen, W. Wang, C. Van Ginneken, S. De Smet, and J. Michiels. 2020. Changes of the glutathione redox system during the weaning transition in piglets, in relation to small intestinal morphology and barrier function. J. Anim. Sci. Biotechnol. 11:45. https://doi.org/10.1186/s40104-020-00440-7.

Diaz, M. C., M. E. Van Amburgh, J. M. Smith, J. M. Kelsey, and E. L. Hutten. 2001. Composition of growth of Holstein calves fed milk replacer from birth to 105-kilogram body weight. J. Dairy Sci. 84:830-842. https://doi.org/10.3168/jds.S0022-0302(01)74541-9.

Dong, X., R. Zhai, Z. Liu, X. Lin, Z. Wang, and Z. Hu. 2019. The effect of intravenous infusions of glutamine on duodenal cell autophagy and apoptosis in early-weaned calves. Animals (Basel) 9:404. https://doi.org/10.3390/ani9070404.

Duttlinger, A. W., K. R. Kpodo, A. P. Schinckel, B. T. Richert, and J. S. Johnson. 2020. Effects of increasing dietary l-glutamine to replace antibiotics on pig health and performance following weaning and transport. Transl. Anim. Sci. 4:txaa157. https://doi.org/ $10.1093 /$ tas $/$ txaa157.

Eckert, E., H. E. Brown, K. E. Leslie, T. J. DeVries, and M. A. Steele. 2015. Weaning age affects growth, feed intake, gastrointestinal development, and behavior in Holstein calves fed an elevated plane of nutrition during the preweaning stage. J. Dairy Sci. 98:6315-6326. https://doi.org/10.3168/jds.2014-9062.

Fleming, S. C., A. Duncan, R. I. Russell, and M. F. Laker. 1996. Measurement of sugar probes in serum: an alternative to urine measurement in intestinal permeability testing. Clin. Chem. 42:445448. https://doi.org/10.1093/clinchem/42.3.445.

Hawkins, A., K. Burdine, D. Amaral-Phillips, and J. H. C. Costa. 2019. An economic analysis of the costs associated with preweaning management strategies for dairy heifers. Animals (Basel) 9:471. https://doi.org/10.3390/ani9070471.

Hawkins, A., K. H. Burdine, D. M. Amaral-Phillips, and J. H. C. Costa. 2020. Effects of housing system on dairy heifer replacement cost from birth to calving: Evaluating costs of confinement, dry lot, and pasture-based systems and their impact on total rearing investment. Front. Vet. Sci. 7:625. https://doi.org/10.3389/fvets .2020 .00625

Hill, T. M., H. G. Bateman II, J. M. Aldrich, and R. L. Schlotterbeck. 2012. Methods of reducing milk replacer to prepare dairy calves for weaning when large amounts of milk replacer have been fed. Prof. Anim. Sci. 28:332-337. https://doi.org/10.15232/S1080 $-7446(15) 30364-8$.

Hsu, C. B., J. W. Lee, H. J. Huang, C. H. Wang, T. T. Lee, H. T. Yen, and B. Yu. 2012. Effects of supplemental glutamine on growth performance, plasma parameters and LPS-induced immune response of weaned barrows after castration. Asian-Australas. J. Anim. Sci. 25:674-681. https://doi.org/10.5713/ajas.2011.11359.

Hu, Z. Y., S. L. Li, and Z. J. Cao. 2012. Short communication: Glutamine increases autophagy of liver cells in weaned calves. J. Dairy Sci. 95:7336-7339. https://doi.org/10.3168/jds.2012-5881.

Hulbert, L. E., and S. J. Moisá. 2016. Stress, immunity, and the management of calves. J. Dairy Sci. 99:3199-3216. https://doi.org/10 $.3168 /$ jds.2015-10198.

Jaeger, B. M., D. Ziegler, D. Schimek, B. Ziegler, H. Chester-Jones, and D. P. Casper. 2020. Dairy calf growth performance when fed a modified accelerated milk replacer program. Appl. Anim. Sci. 36:352-366. https://doi.org/10.15232/aas.2019-01878.

Jafari, A., D. G. V. Emmanuel, R. J. Christopherson, J. R. Thompson, G. K. Murdoch, J. Woodward, C. J. Field, and B. N. Ametaj. 2006. Parenteral administration of glutamine modulates acute phase re- sponse in postparturient dairy cows. J. Dairy Sci. 89:4660-4668. https://doi.org/10.3168/jds.S0022-0302(06)72516-4.

Ji, F. J., L. X. Wang, H. S. Yang, A. Hu, and Y. L. Yin. 2019. Review: The roles and functions of glutamine on intestinal health and performance of weaning pigs. Animal 13:2727-2735. https://doi.org/ 10.1017/S1751731119001800.

Johnson, J. S., and D. C. Lay Jr.. 2017. Evaluating the behavior, growth performance, immune parameters, and intestinal morphology of weaned piglets after simulated transport and heat stress when antibiotics are eliminated from the diet or replaced with L-glutamine. J. Anim. Sci. 95:91-102. https://doi.org/10.2527/jas .2016 .1070 .

Khan, M. A., A. Bach, D. M. Weary, and M. A. G. von Keyserlingk. 2016. Invited review: Transitioning from milk to solid feed in dairy heifers. J. Dairy Sci. 99:885-902. https://doi.org/10.3168/jds.2015 $-9975$.

Khan, M. A., H. J. Lee, W. S. Lee, H. S. Kim, K. S. Ki, T. Y. Hur, G. H. Suh, S. J. Kang, and Y. J. Choi. 2007. Structural growth, rumen development, and metabolic and immune responses of Holstein male calves fed milk through step-down and conventional methods. J. Dairy Sci. 90:3376-3387. https://doi.org/10.3168/jds 2007-0104.

Khan, M. A., D. M. Weary, and M. A. G. von Keyserlingk. 2011. Invited review: Effects of milk ration on solid feed intake, weaning and performance in dairy heifers. J. Dairy Sci. 94:1071-1081. https://doi.org/10.3168/jds.2010-3733.

Kim, M. H., J. Yang, S. D. Upadhaya, H. Lee, C. Yun, and J. K. Ha. 2011. The stress of weaning influences serum levels of acute-phase proteins, iron-binding proteins, inflammatory cytokines, cortisol, and leukocyte subsets in Holstein calves. J. Vet. Sci. 12:151-157. https://doi.org/10.4142/jvs.2011.12.2.151.

Kvidera, S. K., E. A. Horst, M. V. Sanz Fernandez, M. Abuajamieh, S. Ganesan, P. J. Gorden, H. B. Green, K. M. Schoenberg, W. E. Trout, A. F. Keating, and L. H. Baumgard. 2017. Characterizing effects of feed restriction on glucagon-like peptide 2 administration on biomarkers of inflammation and intestinal morphology. J. Dairy Sci. 100:9402-9417. https://doi.org/10.3168/jds.2017-13229.

Le Floc'h, N., C. Deblanc, R. Cariolet, A. V. Gautier-Bouchardon, E. Merlot, and G. Simon. 2014. Effect of feed restriction on performance and postprandial nutrient metabolism in pigs co-infected with Mycoplasma hyopneumoniae and swine influenza virus. PLoS One 9:e104605. https://doi.org/10.1371/journal.pone.0104605.

Leaver, J. D., and N. H. Yarrow. 1972. Rearing of dairy cattle. Weaning calves according to their concentrate intake. Anim. Sci. 14:161165. https://doi.org/10.1017/S0003356100010837.

Lee, D. N., Y. H. Cheng, F. Y. Wu, H. Sato, I. Shinzato, S. P. Chen, and H. T. Yen. 2003. Effect of dietary glutamine supplement on performance and intestinal morphology of weaned pigs. AsianAustralas. J. Anim. Sci. 16:1770-1776. https://doi.org/10.5713/ ajas.2003.1770.

McCracken, B. A., M. E. Spurlock, M. A. Roos, F. A. Zuckermann, and H. R. Gaskins. 1999. Weaning anorexia may contribute to local inflammation in the piglet small intestine. J. Nutr. 129:613619. https://doi.org/10.1093/jn/129.3.613.

McLamb, B. L., A. J. Gibson, E. L. Overman, C. Stahl, and A. J. Moeser. 2013. Early weaning stress in pigs impairs innate mucosal immune responses to enterotoxigenic E. coli challenge and exacerbates intestinal injury and clinical disease. PLoS One 8:e59838 https://doi.org/10.1371/journal.pone.0059838.

Moeser, A. J., C. V. Klok, K. A. Ryan, J. G. Wooten, D. Little, V. L. Cook, and A. T. Blikslager. 2007. Stress signaling pathways activated by weaning mediate intestinal dysfunction in the pig. Am. J. Physiol. Gastrointest. Liver Physiol. 292:G173-G181. https://doi .org/10.1152/ajpgi.00197.2006.

Moeser, A. J., C. S. Pohl, and M. Rajput. 2017. Weaning stress and gastrointestinal barrier development: implications for lifelong gut health in pigs. Anim. Nutr. 3:313-321. https://doi.org/10.1016/j .aninu.2017.06.003.

Owen, F. G., and L. L. Larson. 1982. A simplified liquid feeding program for calves. J. Dairy Sci. 65:1350-1356. https://doi.org/10 .3168/jds.S0022-0302(82)82352-7. 
Pié, S., J. P. Lallès, F. Blazy, J. Laffitte, B. Sève, and I. P. Oswald. 2004. Weaning is associated with an upregulation of expression of inflammatory cytokines in the intestine of piglets. J. Nutr. 134:641-647. https://doi.org/10.1093/jn/134.3.641.

Pluske, J. R., M. J. Thompson, C. S. Atwood, P. H. Bird, L. H. Williams, and P. E. Hartmann. 1996. Maintenance of villus height and crypt depth, and enhancement of disaccharide digestion and monosaccharide absorption, in piglets fed on cows' whole milk after weaning. Br. J. Nutr. 76:409-422. https://doi.org/10.1079/ BJN19960046.

Potsic, B., N. Holliday, P. Lewis, D. Samuelson, V. DeMarco, and J. Neu. 2002. Glutamine supplementation and deprivation: Effect on artificially reared rat small intestinal morphology. Pediatr. Res. 52:430-436. https://doi.org/10.1203/00006450-200209000-00021.

Qin, Q., X. Xu, X. Y. Wang, H. Wu, H. Zhu, Y. Hou, B. Dai, X. Liu, and Y. Liu. 2018. Glutamate alleviates intestinal injury, maintains mTOR and suppresses TLR4 and NOD signaling pathways in weanling pigs challenged with lipopolysaccharide. Sci. Rep. 8:15124. https://doi.org/10.1038/s41598-018-33345-7.

Quigley, J. D. III, Z. P. Smith, and R. N. Heitmann. 1991. Changes in plasma volatile fatty acids in response to weaning and feed intake in young calves. J. Dairy Sci. 74:258-263. https://doi.org/10.3168/ jds.S0022-0302(91)78168-X.

Rogero, M. M., M. C. Borges, I. A. de Castro, I. S. Pires, P. Borelli, and J. Tirapegui. 2011. Effects of dietary glutamine supplementation on the body composition and protein status of early-weaned mice inoculated with Mycobacterium bovis Bacillus CalmetteGuerin. Nutrients 3:792-804. https://doi.org/10.3390/nu3090792.

Sellmann, C., C. J. Jin, C. Degen, J.-P. De Bandt, and I. Bergheim. 2015. Oral glutamine supplementation protects female mice from nonalcoholic steatohepatitis. J. Nutr. 145:2280-2286. https://doi .org/10.3945/jn.115.215517.

Smith, F., J. E. Clark, B. L. Overman, C. C. Tozel, J. H. Huang, J. E. Rivier, A. T. Blikslager, and A. J. Moeser. 2010. Early weaning stress impairs development of mucosal barrier function in the porcine intestine. Am. J. Physiol. Gastrointest. Liver Physiol. 298:G352-363. https://doi.org/10.1152/ajpgi.00081.2009.

Soberon, F., E. Raffrenato, R. W. Everett, and M. E. Van Amburgh. 2012. Preweaning milk replacer intake and effects on long-term productivity of dairy calves. J. Dairy Sci. 95:783-793. https://doi .org/10.3168/jds.2011-4391.

Steele, M. A., J. H. Doelman, L. N. Leal, F. Soberon, M. Carson, and J. A. Metcalf. 2017. Abrupt weaning reduces postweaning growth and is associated with alterations in gastrointestinal markers of development in dairy calves fed an elevated plane of nutrition during the preweaning period. J. Dairy Sci. 100:5390-5399. https:// doi.org/10.3168/jds.2016-12310.

Turner, J. R. 2009. Intestinal mucosal barrier function in health and disease. Nat. Rev. Immunol. 9:799-809. https://doi.org/10.1038/ nri2653.

Urie, N. J., J. E. Lombard, C. B. Shivley, C. A. Kopral, A. E. Adams, T. J. Earleywine, J. D. Olson, and F. B. Garry. 2018. Preweaned heifer management on US dairy operations: Part I. Descriptive characteristics of preweaned heifer raising practices. J. Dairy Sci. 101:9168-9184. https://doi.org/10.3168/jds.2017-14010.

USDA. 2016. Dairy 2014, Dairy Cattle Management Practices in the United States, 2014. USDA-APHIS: VS-CEAH-NAHMS.

van Keulen, P., M. Khan, J. Dijkstra, F. Knol, and S. Mccoard. 2020. Effect of arginine or glutamine supplementation and milk feeding allowance on small intestine development in calves. J. Dairy Sci 103:4754-4764. https://doi.org/10.3168/jds.2019-17529.

Van Soest, P. J., J. B. Robertson, and B. A. Lewis. 1991. Methods for dietary fiber, neutral detergent fiber, and nonstarch polysaccharides in relation to animal nutrition. J. Dairy Sci. 74:3583-3597. https://doi.org/10.3168/jds.S0022-0302(91)78551-2.

Weary, D. M., J. Jasper, and M. J. Hötzel. 2008. Understanding weaning distress. Appl. Anim. Behav. Sci. 110:24-41. https://doi.org/ 10.1016/j.applanim.2007.03.025.

Wickramasinghe, H. K. J. P., A. J. Kramer, and J. A. D. R. N. Appuhamy. 2019. Drinking water intake of newborn dairy calves and its effects on feed intake, growth performance, health status, and nutrient digestibility. J. Dairy Sci. 102:377-387. https://doi.org/ $10.3168 /$ jds.2018-15579.

Winchester, C. F., and M. J. Morris. 1956. Water intake rates of cattle. J. Anim. Sci. 15:722-740. https://doi.org/10.2527/jas1956 $.153722 \mathrm{x}$.

Wolk, K., E. Witte, U. Hoffmann, W. D. Doecke, S. Endesfelder, K. Asadullah, W. Sterry, H. D. Volk, B. M. Wittig, and R. Sabat. 2007. IL-22 induces lipopolysaccharide-binding protein in hepatocytes: a potential systemic role of IL-22 in Crohn's disease. J. Immunol. 178:5973-5981. https://doi.org/10.4049/jimmunol.178.9 .5973 .

Wood, K. M., S. Palmer, M. A. Steele, J. A. Metcalf, and G. B. Penner. 2015. The influence of age and weaning on permeability of the gastrointestinal tract in Holstein bull calves. J. Dairy Sci 98:7226-7237. https://doi.org/10.3168/jds.2015-9393.

Wright, S. D., R. A. Ramos, P. S. Tobias, R. J. Ulevitch, and J. C. Mathison. 1990. CD14, a receptor for complexes of lipopolysaccharide (LPS) and LPS binding protein. Science 249:1431-1433. https: //doi.org/10.1126/science.1698311.

Wu, G., S. A. Meier, and D. A. Knabe. 1996. Dietary glutamine supplementation prevents jejunal atrophy in weaned pigs. J. Nutr. 126:2578-2584. https://doi.org/10.1093/jn/126.10.2578.

\section{ORCIDS}

H. K. J. P. Wickramasinghe $\odot$ https://orcid.org/0000-0002-9493-1513

C. A. Kaya @ https://orcid.org/0000-0001-8226-7603

L. H. Baumgard () https://orcid.org/0000-0002-3077-5996

J. A. D. R. N. Appuhamy @ https://orcid.org/0000-0001-8767-0303 